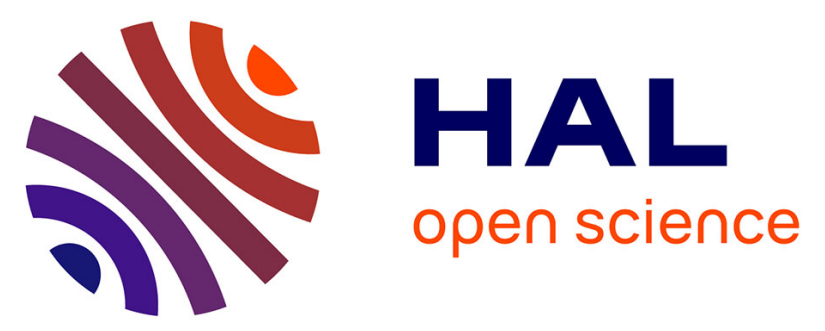

\title{
Structure-activity relationships of some hederagenin diglycosides: Haemolysis, cytotoxicity and apoptosis induction
}

Martin Chwalek, Nathalie Lalun, Hélène Bobichon, Karen Plé, Laurence Voutquenne-Nazabadioko

\section{To cite this version:}

Martin Chwalek, Nathalie Lalun, Hélène Bobichon, Karen Plé, Laurence Voutquenne-Nazabadioko. Structure-activity relationships of some hederagenin diglycosides: Haemolysis, cytotoxicity and apoptosis induction. Biochimica et Biophysica Acta (BBA) - General Subjects, 2006, 1760 (9), pp.14181427. 10.1016/j.bbagen.2006.05.004 . hal-01996864

\section{HAL Id: hal-01996864 \\ https://hal.univ-reims.fr/hal-01996864}

Submitted on 22 Sep 2021

HAL is a multi-disciplinary open access archive for the deposit and dissemination of scientific research documents, whether they are published or not. The documents may come from teaching and research institutions in France or abroad, or from public or private research centers.
L'archive ouverte pluridisciplinaire HAL, est destinée au dépôt et à la diffusion de documents scientifiques de niveau recherche, publiés ou non, émanant des établissements d'enseignement et de recherche français ou étrangers, des laboratoires publics ou privés. 
Structure-activity relationships of some hederagenin diglycosides : haemolysis, cytotoxicity and apoptosis induction

\author{
Martin Chwalek $^{a}$, Nathalie Lalun ${ }^{b}$, Hélène Bobichon ${ }^{c}$, Karen Pléa, Laurence \\ Voutquenne-Nazabadioko ${ }^{\mathrm{a}^{*}}$ \\ ${ }^{a}$ CNRS FRE 2715 Université de Reims Champagne-Ardenne, IFR 53 Biomolécules \\ CPCBAI, Bât. 18, Moulin de la Housse, BP 1039, 51687 Reims, France \\ ${ }^{b}$ Laboratoire de Biologie cellulaire, Histologie, Cytogénétique, UFR Médecine, \\ 51, rue Cognacq-Jay, 51096 Reims Cedex, France \\ ${ }^{\mathrm{c}}$ Unité MEDIAN, Université de Reims Champagne-Ardenne, IFR 53 Biomolécules \\ 51, rue Cognacq-Jay, 51096 Reims Cedex, France
}

\footnotetext{
* Corresponding author. Tel.: +33 3269182 08; Fax: +33 326913596

E-mail address: laurence.voutquenne@univ-reims.fr (L. Voutquenne)
} 


\begin{abstract}
Hederagenin saponins are largely represented in nature and possess many biological activities such as haemolytic, antiviral, fungicidal, molluscicidal or cytotoxic, partially due to their interaction with the cell membrane. The lysis of erythrocytes (haemolysis) is a simple test to evaluate this adsorption, and this activity has been linked to the structure of the aglycone and also depends on the sugar moiety of the saponin. To further complete our study of the structure-activity relationships of triterpenoid saponins, $\alpha$-hederin and related hederagenin diglycosides were synthesized to better understand the influence of the second sugar $(\alpha-\mathrm{L}-$ rhamnose, $\beta$-D-xylose or $\beta$-D-glucose) and the substitution of this sugar on $\alpha$-L-arabinose (position 2, 3 or 4). Haemolysis and cytotoxic activity on KB cells were tested. These compounds probably interact with membrane cholesterol and produce destabilization of the membrane inducing haemolysis. Cytotoxicity could involve the same mechanism, although some saponins induce an apoptotic process. The nuclear structure of the KB cell was thus investigated by confocal microscopy. The cytotoxic activity of a second group of hederagenin glucoside saponins was also evaluated. Our results showed that cytotoxicity was a result of both the sugar part and the structure of genin (carboxylic acid or methyl ester).
\end{abstract}

Keywords: $\alpha$-Hederin; Saponin; Hederagenin; Haemolysis; Cytotoxicity; KB cells 


\section{Introduction}

Saponins are triterpene or steroid glycosides found in a wide variety of plants and certain marine organisms possessing various biological and pharmacological activities [1]. Their biological activities are closely related to their chemical structures which determine polarity, hydrophobicity and acidity. The lysis of red blood cells by saponins is the result of interactions with membrane cholesterol [1] forming pits and holes [2-4], which produce a destabilisation of the membrane by a micellar type-arrangement [5]. In the study of saponin structure-activity relationships, both the aglycone and the sugar moiety play an important role in the evaluation of biological activity [6-10]. Haemolytic activity depends on the nature, number and sequence of the sugars in the saponin, and most existing structure-activity relationships have focused either on the aglycone or on the number of sugar units involved [6, 7, 9, 10]. As structure-activity relationships of certain synthetic triterpenoid or steroid saponins have been previously established [9, 11-15], it has been shown that the effect of the sugar residue on haemolytic activity is not transferable from one aglycone to another $[9,15]$. With aglycones possessing a carboxylic acid in position 28 , the haemolytic activity is greater when the acid is esterified as a methyl ester $[6,8,16]$.

Many hederagenin containing saponins have been shown to possess haemolytic activity [7]. $\alpha$-hederin (1) and $\delta$-hederin (2) are natural triterpenoids widely distributed in higher plants $[1,17-22]$. In addition to molluscicidal $[18,20]$ and cytotoxic $[22,23]$ activities, $\alpha-$ hederin possesses strong haemolytic activity [7, 19] and reveals cytotoxicity against various cancer cell lines and in vivo tumours [21, 22, 24-29]. It has been proposed that the mechanism by which $\alpha$-hederin induces cell destruction could be apoptosis [29] and/or membrane alterations [25]. Certain authors have hypothesized that the $\alpha$-L-Rhap-( $1 \rightarrow 2)-\alpha$-L-Arap osidic sequence is essential for the cytotoxic activity of hederagenin saponins [21] as a change in the 
sugar moiety influences cytotoxic activity $[23,30]$. However, in the literature, comparative structure-activity relationship studies of both haemolytic and cytotoxic activities are few [30].

For the past several years, our laboratory has been interested in haemolytic structureactivity relationships of triterpenoid saponins $[7,8]$. In order to further develop our study of hederagenin saponins [8], we analyzed the activity of hemi-synthetic saponins derived from $\delta$ hederin by varying the type and position of the sugar unit attached to the $\alpha$-L-arabinose. In the first part of this study, the haemolytic activity of thirteen synthetic hederagenin saponins and their methyl esters was measured to verify whether both the type and position of the sugar influence the two series in the same manner. The tested saponins were $\delta$-hederin $(\mathbf{1}), \alpha-$ hederin (2) and its positional disaccharide isomers bearing an $\alpha$-L-rhamnopyranose attached to positions 3 or 4 of the $\alpha$-L-arabinopyranose (4-5) [31]. Two distinct families in which the Larabinopyranose was glycosylated in positions 2,3 or 4 with a $\beta$-D-xylopyranose (6-9) or a $\beta$ D-glucopyranose (10-13) residue, were also prepared [32] and tested, as well as saponins $\mathbf{3}, \mathbf{7}$ and 11, having a non-naturally occurring $\beta$ configuration between the aglycone and the sugar chain. The cytotoxic activity of the hemi-synthetic saponins on KB cells is reported in a second part, in order to verify the importance of the sugar chain and to establish structureactivity relationships. The range of molecules tested was extended to include hemi-synthetic hederagenin diglycoside saponins containing a $\beta$-D-glucose as the first sugar (14-19) as well as their methyl esters (14a-19a) [8]. Finally, as apoptosis is a process of programmed cell death, characterized at the nuclear level by the condensation of chromatin and DNA fragmentation, the influence of some saponins on the structure of the cell nucleus was studied. Haemolysis, cytotoxicity and apoptosis results of all tested saponins in their two forms were then compared to clarify the possible link between these two biological activities.

Fig. 1 and 2 near here 


\section{Materiels and methods}

\subsection{Chemicals}

DMSO, MTT, and Chromomycine A3, were purchased from Sigma-Aldrich ${ }^{\circledR}$ Munich, Germany. SN-38 or 7-ethyl-10-hydroxycamptothecin was purchased from Qventas, Newark, DE, USA. All other chemicals were of analytical grade purity.

\subsection{Saponin hemi-synthesis}

$\delta$-Hederin (1), $\alpha$-hederin (2) and its eleven analogues (Fig. 1) were synthesized using previously described chemical methods $[31,32]$. Synthesis of the other diglycosides saponins using six commercial disaccharides (Fig. 2) was also previously described [8]. All of the tested saponins were $\geq 95 \%$ pure (HPLC).

\subsection{Haemolysis}

Sheep erythrocytes were purchased from Eurobio ${ }^{\circledR}$ with a determined hematocrite level. This suspension was diluted with phosphate buffer saline (PBS) (pH 7.4) in order to obtain a $10 \%$ erythrocyte solution. Mother saponin solutions $(500 \mu \mathrm{g} / \mathrm{ml})$ were freshly prepared by dissolving the saponin in DMSO, then adding PBS to obtain a solution of 5:1 DMSO/PBS; 1 ml samples were prepared in PBS with concentrations ranging from 1 to $100 \mu \mathrm{g} / \mathrm{ml}$ (no damage of the erythrocytes by DMSO occurred at $100 \mu \mathrm{g} / \mathrm{ml})$. Each concentration was done in triplicate. The erythrocyte suspension $(25 \mu \mathrm{l})$ was added to $1 \mathrm{ml}$ of the solution to be tested 
and the samples were rapidly stirred and incubated at $37{ }^{\circ} \mathrm{C}$ for $60 \mathrm{~min}$. Periodic stirring during the incubation period was performed. The solutions were then centrifuged at $3000 \mathrm{rpm}$ for $5 \mathrm{~min}$. Absorbance of the supernatant was measured at $540 \mathrm{~nm}$ and the haemolysis percentage was calculated by comparison with $100 \%$ haemolysis caused by the Sigma ${ }^{\circledR}$ dialyzed mixture [8]. $\mathrm{HD}_{50}$ and $\mathrm{HD}_{100}$ values were the sample concentrations that caused $50 \%$ and $100 \%$ haemolysis.

\subsection{Essay for growth inhibition}

\subsubsection{Cell culture}

The KB cell line DSMZ ACC136 was purchased from Interchim ${ }^{\circledR}$. Cells were grown at 37 ${ }^{\circ} \mathrm{C}$ in Dulbecco's modified Eagle's medium (DMEM) supplemented with $10 \%$ of foetal calf serum (FCS) (Gibco) in a humidified atmosphere containing $5 \% \quad \mathrm{CO}_{2}$. Logarithmically growing cells were seeded in $25 \mathrm{~cm}^{2}$ Nunclon tissue culture flasks at a density of $50.10^{3} \mathrm{c} / \mathrm{ml}$ in $5 \mathrm{ml}$, twice a week.

\subsubsection{Experiments}

To evaluate the effect of the nutrient medium, experiments were first performed in parallel in DMEM-10\% FCS and in HAM F12 (Gibco) without FCS. Logarithmically growing KB cells were seeded for $24 \mathrm{~h}$ into a 96 well plate (Nunclon) (200 $\mu 1$ of DMEM-10\% FCS per well with $50.10^{3} \phi / \mathrm{ml}$ ) for adhesion. The cytotoxic activity of $\alpha$-hederin (2) was tested in both mediums. The mother saponin solution $(1 \mathrm{mg} / \mathrm{ml})$ was prepared by dissolving $\alpha$-hederin in DMSO and then sample dilutions were prepared in both mediums. After removal of the medium, $200 \mu \mathrm{l}$ of DMEM-10\% FCS or HAM F12 containing different concentrations of the saponin $(1,2.5,5,7.5$ or $10 \mu \mathrm{g} / \mathrm{ml})$ were added. Each concentration was done in triplicate. 
$\mathrm{IC}_{50}$ values, concentration which inhibit $50 \%$ of growing cells, were determined after $48 \mathrm{~h}$ of incubation using the MTT test. The OD was measured at $540 \mathrm{~nm}$.

For the others saponins, a mother saponin solution $(1 \mathrm{mg} / \mathrm{ml})$ was prepared by dissolving the saponin in DMSO. Sample dilutions ranging from 1 to $10 \mu \mathrm{g} / \mathrm{ml}$ were then prepared by diluting in HAM F12. $\mathrm{IC}_{50}$ values for these saponins were determined after $48 \mathrm{~h}$ of incubation as described for $\alpha$-hederin with Ham F-12 as the nutrient medium.

\subsection{Nuclei analysis by confocal microscopic imaging}

This analysis concerned $\delta$-hederin $(\mathbf{1}), \alpha$-hederin $(\mathbf{2})$ and several analogues $(\mathbf{3 - 5}, \mathbf{6}, \mathbf{8}, \mathbf{1 0}$, 13) and their methyl esters (1a-3a, 6a, 8a, 10a, 13a).

From exponentially growing cultures, $\mathrm{KB}$ cells were plated onto microscopic slides at $25.10^{3} \phi / \mathrm{ml}$ in DMEM-10\% FCS medium, in 24 well plates, for $24 \mathrm{~h}$, to allow the cells to adhere. Saponins in HAM F12 were then added, after rinsing the cells with PBS, at concentrations just below the $\mathrm{IC}_{50}$, for $48 \mathrm{~h}$. Cells were rinsed 3 times with PBS, and then fixed with paraformaldehyde 4\% PBS with Triton X100 0.1\%, for 5 min. After rinsing 3 times with PBS, Chromomycin A3 was added at $0.1 \mathrm{mg} / \mathrm{ml}$ in $\mathrm{PBS}-\mathrm{MgCl}_{2}$ for 10 to $15 \mathrm{~min}$. After rinsing, slides were mounted with Citifluor anti-fading agent. Observation was performed with Biorad MRC 1024 S confocal microscope. Percentages of mitotic and apoptotic figures were calculated from the observation of 150 cells. A confocal assistant system was used for image treatment and measurement of nuclei diameters (apoptotic and mitotic nuclei were excluded).

\section{Results}




\subsection{Haemolysis}

The haemolytic activities of saponins containing L-arabinose (1-13) are shown in Fig. 3 and the haemolytic activities of their methyl esters (1a-13a) are shown in Fig. 4.

\section{Fig 3 near here}

$\delta$-Hederin (1), having one sugar for the osidic chain, showed a considerable haemolytic activity, slightly less active than $\alpha$-hederin (2) (Fig. 3). Comparing the activities of saponins 2-5 with an $\alpha$-L-rhamnopyranose, showed that saponin 3, with a $\beta$-L anomeric configuration for the arabinopyranose, had only a weak activity at the strongest concentration tested. When considering $\mathrm{HD}_{50}$, the substitution in position 2 of the $\alpha$-L-arabinopyranose (2), was approximately two times more haemolytic than substitution in position 3 (4) and five times more haemolytic than compound 5 having a $(1 \rightarrow 4)$ interglycosidic linkage. The activity of saponins 6-9 with a $\beta$-D-xylopyranose, showed that saponin 7, possessing the $\beta$-Larabinopyranose anomeric configuration, was inactive at the concentrations tested. The activity slightly increased in the order $8((1 \rightarrow 3)$ linkage $), 6((1 \rightarrow 2)$ linkage $)$ and $9((1 \rightarrow 4)$ linkage). In the glucose series (10-13), saponins 10 and 11 having a $(1 \rightarrow 2)$ linkage, showed no haemolytic activity. In contrast to the series of saponins with an $\alpha$-L-rhamnopyranose $(\mathbf{2}, \mathbf{4}$, 5) or a $\beta$-D-xylopyranose $(\mathbf{6}, \mathbf{8}, \mathbf{9})$, the most active saponin possessed a $(1 \rightarrow 4)$ interglycosidic linkage (13).

An overall increase in haemolysis was observed for the methyl esters saponins 1a-13a (Fig. 4) as compared to the corresponding free carboxylic acids (Fig. 3). Three exceptions were observed with compounds $\mathbf{4 a}$ and $8 \mathbf{a}$ possessing a $(1 \rightarrow 3)$ linkage and $\mathbf{1 3 a}$ with a $(1 \rightarrow 4)$ 
linkage. The activity of these compounds was virtually identical to that of the free acid hederagenin derivatives $\mathbf{4 , 8}$ and 13 .

\section{Fig. 4 near here}

The increase in haemolytic activity of the saponins was very significant especially in the case of saponin 10a possessing a $(1 \rightarrow 2)$ interglycosidic linkage between a $\beta$-D-glucose and an $\alpha$-L-arabinose. Whereas this compound was inactive in its natural form (10), its methyl ester was the most haemolytic saponin. This saponin was approximately three fold more active than saponin 13a having the $(1 \rightarrow 4)$ linkage. For the esterified saponins $(\mathbf{1 a - 1 3 a})$, the order of haemolytic activity in each series was not the same as in the free carboxylic acid series. $\alpha$ Hederin methyl ester $(\mathbf{2 a})$ possessing a $(1 \rightarrow 2)$ interglycosidic linkage between $\alpha$-L-rhamnose and $\alpha$-L-arabinose was one of the two most active saponins. The least active saponins were once again, those having a $\beta$ anomeric configuration for the L-arabinose (3a, 7a, 11a). Saponin 7a had, however, a haemolytic activity of $100 \%$ at the highest concentration tested.

\subsection{Essay for growth inhibition}

\subsubsection{Influence of the culture medium}

Previous studies have shown that bovine serum albumin (BSA) and foetal calf serum (FCS) decreased the cytotoxicity of $\alpha$-hederin [25] and other saponins [33]. As cells are routinely cultured in DMEM-10\% FCS, cell growth was compared with DMEM-10\% FCS and with HAM F12 without serum and was identical after $72 \mathrm{~h}$ of culture. The doubling time was $21.8 \mathrm{~h}(1.1$ per $24 \mathrm{~h})$. The cytotoxicity of $\alpha$-hederin (2), at the highest concentration tested $(10 \mu \mathrm{g} / \mathrm{ml}=13.3 \mu \mathrm{M})$ was $29 \%$ in DMEM-10\% FCS and 97\% in HAM F12, in agreement with Danloy et al. [25]. Consequently, tests were performed with HAM F12. 


\subsubsection{Cytotoxic activity of the L-arabinose containing saponins 1-13 and 1a-13a}

As for haemolytic activity, the cytotoxic activity results were divided into 2 groups: $\delta$ hederin (1), $\alpha$-hederin (2) and their derived free carboxylic acid saponins 3-13 (Fig. 5) and the methyl ester derivatives 1a-13a (Fig. 6). SN 38 was used as a control.

\section{Fig. 5 near here}

$\alpha$-Hederin (2) was again the most active compound with an $\mathrm{IC}_{50}$ of $5.5 \mu \mathrm{M}$, similar to those obtained on other cell lines [21, 27-28].

In the first group, no $\mathrm{IC}_{50}$ could be determined for the saponins possessing a $\beta$-L-arabinose $(3,7,11)$ as these compounds were only slight active. Among the saponins having an $\alpha$-Lrhamnose as a second sugar, only $\alpha$-hederin $(2)((1 \rightarrow 2)$ linkage) and saponin $4((1 \rightarrow 3)$ linkage) showed cytotoxic activity. When the $\alpha$-L-arabinose was substituted by a $\beta$-D-xylose $(6,8,9)$, growth inhibition was similar whatever the substitution position. Between saponins having a $\beta$-D-glucose as a second sugar $(\mathbf{1 0}, \mathbf{1 2}, \mathbf{1 3})$, saponin $10((1 \rightarrow 2)$ linkage $)$, was only slightly cytotoxic at the concentrations tested. Saponins $12((1 \rightarrow 3)$ linkage $)$ and $\mathbf{1 3}((1 \rightarrow 4)$ linkage) were less active than $\alpha$-hederin, as observed on other cell lines [24, 26].

\section{Fig. 6 near here}

Comparison of the activities of compound $\mathbf{1}$ (Fig. 5) and 1a (Fig. 6), revealed that the esterification of $\delta$-hederin (1a), induced a decrease in cytotoxic activity. Esterification of $\alpha$ hederin (2a) had no influence on the inhibition of $\mathrm{KB}$ cell growth, as result previously observed against HL-60 cells with both hederagenin and oleanolic acid saponins [26]. For the other methylated saponins having an $\alpha$-L-rhamnose as a second sugar (3a-5a), the cytotoxic activity slightly increased for compound $\mathbf{3 a}$, possessing a $\beta$-L-arabinose, and $\mathbf{5 a}$, which were 
inactive in their carboxylic forms. On the other hand, the cytotoxicity of compound $4 \mathbf{a}$ decreased when compared to 4 . When the L-arabinose was substituted by a $\beta$-D-xylose (6a9a), cytotoxic activity decreased after esterification except for compound $7 \mathbf{a}$, possessing a $\beta$ L-arabinose anomeric configuration. Compound 8a $((1 \rightarrow 3)$ linkage) was almost not cytotoxic compared to its natural form $(\mathbf{8})$. In the glucose series (10a-13a), esterification decreased the cytotoxic activity except for saponin 10a $((1 \rightarrow 2)$ linkage). Compound 11a, possessing a $\beta$-Larabinose, was the least cytotoxic.

\subsection{Haemolytic and cytotoxic activity of $\beta$-D-glucose containing saponins 14-19 and 14a-19a}

Hederagenin galactosyl-glucosides and diglucosides (14-19) and their corresponding methyl esters (14a-19a) were previously tested in order to evaluate the influence of the position ( 4 or 6 ), the configuration ( $\alpha$ or $\beta$ ) of the second sugar as well as the type of terminal sugar (D-glucose or D-galactose) on the haemolytic activity [8]. These results are reported in Table 1. As observed with L-arabinose disaccharides, the saponin methyl esters were more active than the free carboxylic acids. Our study showed that for both methyl ester and free acids, a $(1 \rightarrow 4)$ linkage between the sugars increased haemolytic activity as compared to a $(1 \rightarrow 6)$ linkage, and that a $\beta$ configuration of the terminal sugar was also favoured. The results were more difficult to interpret for the choice of the terminal sugar. In our study, a galactose residue was preferred in the methyl ester saponin series, and a glucose residue was preferred in the free acid saponins [8].

Only a slight cytotoxic activity was observed for the free carboxylic acid saponins 14-19 (Table 1). With esterified saponins 14a-19a, a decrease in cytotoxicity was observed when compared to the free acid saponins except for compounds 14a, 15a and 16a, possessing a $(1 \rightarrow 4)$ linkage with a $\beta$-D-glucose. The cellobiosyl (14a) and lactosyl (15a) saponins, in 
which the terminal sugar has a $\beta$ anomeric configuration, were the most cytotoxic, this tendency being previously observed with haemolytic activity.

\subsection{Nuclei analysis}

Labelling with Chromomycin A3, and observation with a confocal microscope allowed the identification of four parameters: the percentage of cells undergoing mitosis or apoptosis, analysis of the chromatin structure and measurement of the nuclear diameter, all of which are affected by treatment with saponins. Results were summarized in Fig. 7 and Table 2.

These results revealed that the structure of the cell nuclei was not dependent on the culture medium. Cultured for $72 \mathrm{~h}$, the cells reached confluence and neither mitosis nor apoptosis could be detected, as previously observed for these culture conditions. The mean diameter of nuclei was $11.6 \mu \mathrm{m}$. In these control cells, chromatin was regularly scattered as clumps within the nucleus with a classical weak condensation around the nucleolus (Fig. 7A).

\section{Fig. 7 near here}

Unfortunately, saponins $\mathbf{6 a}, \mathbf{8 a}, \mathbf{1 0 a}$ and 13a induced the loss of cell adhesion on the slides. The treatment of KB cells with the other saponins induced alterations whose amplitude varied within the cell population. Treated cells never reached confluence, whatever the compound used. Although some cells maintained a typical nuclear structure (Fig. 7E, F, K), that of the other nuclei was modified in four ways and the intensity of the observed modifications was largely dose-dependent $(\mathbf{2}, \mathbf{2 a}, \mathbf{3}, \mathbf{3 a}$ and $\mathbf{8})$.

Firstly, enlargement of the cell nuclei diameter was associated with weak structural modifications (Fig. 7B): the perinucleolar condensation of chromatin was maintained as well as the presence of clumps in the nucleoplasm $(\mathbf{1}, \mathbf{2})$. Secondly, the presence of true apoptotic figures with the classical intensive condensation of chromatin (Fig. 7B', F') was observed 
with saponins $\mathbf{1}, \mathbf{3}, \mathbf{3 a}, \mathbf{4}, \mathbf{6}, \mathbf{8}, \mathbf{1 0}$ and 13. Thirdly, saponins 1, 2, and 2a induced a low apoptotic process that lead to the presence of intermediate steps seen by the condensation of chromatin around the nucleolus and lining the nuclear envelope (Fig. 7C, D, E') which left the nucleoplasm empty. The last type of modification consisted of an increased number of chromatin clumps corresponding to a granular aspect of the chromatin (Fig. 7I, J) or a decondensation of the chromatin which appeared smooth in the whole nucleus (Fig. 7G, H, L).

When considering the nuclear diameters (Table 2), the most prominent result consisted of a homogeneous enlargement of the nuclei which was observed with saponins 1 or $3 \mathbf{a}$. On the other hand, with saponins $2, \mathbf{3}, \mathbf{2 a}, \mathbf{3 a}, \mathbf{6}$ and $\mathbf{8}$, a weak decrease in the mean diameter was observed $(\sim 10 \mu \mathrm{m})$.

The percentages of mitosis and apoptosis, when compared to the control cells, showed that the treated ones exhibited a slower growth rate as some mitosis was detected for a cell population under confluence. In most of the cases, the presence of mitosis was associated with apoptosis which was particularly high for compounds $\mathbf{3 ,} \mathbf{8}$ and $\mathbf{1 3}$.

\section{Discussion}

Saponins possess detergent-like properties. They can also increase the permeability of cell membranes without destroying them [34]. In the case of erythrocytes, complexation of saponins with cholesterol results in rapid cell lysis [7, 35]. Saponins could also affect the interaction between trans-membrane proteins such as $\mathrm{Na}^{+}, \mathrm{K}^{+}$-ATPase and proteins of the cytoskeleton related to the cell membrane $[36,37]$. It is known that saponin interactions with the cell membrane are dependent on the structure of the genin as well as the sugar moiety [38]. When comparing the cytotoxic activity and the haemolytic activity of different triterpene 
bidesmoside saponins, Bader et al. concluded that these two activities were directly correlated [30].

In this study, $\alpha$-hederin (2) is the most active molecule of the tested saponins. Our results seemed to confirm the hypothesis that the sequence $\alpha$-L-Rhap- $(1 \rightarrow 2)-\alpha$-L-Arap is characteristic of the more cytotoxic saponins with oleanolic acid or hederagenin [21, 22]. However, the mechanism of action for $\alpha$-hederin is not clearly established and this saponin is as active on cancerous cells as on non cancerous ones [22].

The presence of a $\beta$-L-arabinopyranose $(\mathbf{3}, \mathbf{7}, \mathbf{1 1}, \mathbf{3 a}, \mathbf{7 a}, \mathbf{1 1 a})$ was related to a lack of determined $\mathrm{HD}_{50}$ or $\mathrm{IC}_{50}$, except for compounds $3 \mathbf{a}$ and $7 \mathbf{a}$ which showed very low activity. These results were similar to those observed with saponins 17-19 and 17a-19a possessing an $\alpha$-D-Glc or an $\alpha$-D-Gal (Table 1). The anomeric configurations ( $\alpha$-D or $\beta$-L) are non natural for saponins and are rarely observed in the plant kingdom. According to our results, the presence of these anomeric configurations, anywhere in the sugar moiety, is unfavourable for both the haemolytic and cytotoxic activities.

We have previously described that the haemolytic activity increases with the length of the osidic chain [7], but Seebacher et al. have observed that this is not always the rule [12]. Our results have also showed that $\delta$-hederin (1), with only one sugar, has a considerable haemolytic activity $\left(\mathrm{HD}_{50}=14.0 \mu \mathrm{M}\right)$, being only slightly less active than $\alpha$-hederin $(2)$, and more haemolytic than most of the saponins having a disaccharide chain (Fig. 3). On the other hand, compound 1 was less cytotoxic than the most of the other saponins (Fig. 5).

In relation to the glycoside chain, the ascending order of activity of saponins $\mathbf{2 - 1 3}$ was parallel when comparing haemolytic activity $\left(\mathrm{HD}_{50}\right)$ and cytotoxic activity on $\mathrm{KB}$ cells $\left(\mathrm{IC}_{50}\right)$, (Fig. 3 and 5). For example, the saponins with a $\beta$-L-arabinose $(\mathbf{3}, \mathbf{7}, \mathbf{1 1})$ as well as akebia saponin C (10) did not present any activity for either test. Compound 5, which had no cytotoxic activity, showed the weakest haemolytic activity ( $\mathrm{HD}_{50}$ at $\left.58.4 \mu \mathrm{M}\right)$ of the $\alpha$-L- 
arabinose containing saponins. Our results with saponins 2-13 showed that neither the intrinsic nature of the second sugar nor the interglycosidic linkages were, in themselves, determinant, but that each sugar was efficient in a specific position. The preferential position of substitution was a $(1 \rightarrow 2)>(1 \rightarrow 3)>(1 \rightarrow 4)$ linkage for the $\alpha$-L-rhamnopyranose series, a $(1 \rightarrow 3)>(1 \rightarrow 2)>(1 \rightarrow 4)$ linkage for the $\beta$-D-xylopyranose family, and a $(1 \rightarrow 4)>(1 \rightarrow 3)>$ $(1 \rightarrow 2)$ linkage for the $\beta$-D-glucopyranose family. The parallel between cytotoxic and haemolytic activity cannot, however, be generalized as observed with $\delta$-hederin $(\mathbf{1})$. With the $\beta$-D-glucose containing saponins $\mathbf{1 4 - 1 9}$, our previous study showed that a $(1 \rightarrow 4)$ linkage between the two hexoses, $\beta$-D-glucose or $\beta$-D-galactose, increased haemolytic activity as compared to a $(1 \rightarrow 6)$ linkage, and that the $\beta$ configuration of the terminal sugar was also favoured [8]. Although saponins $\mathbf{1 4}, \mathbf{1 5}$ and $\mathbf{1 6}$ are haemolytic, no $\mathrm{IC}_{50}$ values were obtained at the highest concentrations tested $(12.5 \mu \mathrm{M})$. The change of arabinose (13) by glucose $(\mathbf{1 4})$ at the first position of the disaccharide chain suppresses cytotoxic activity, probably because glucose is rapidly hydrolysed into the cell [22].

It has been described that genin esterification increases haemolytic activity by reducing polarity [6]. Overall, this same phenomenon was observed in our study, except for compounds 4a and 8a that were as active as their carboxylic acid counterparts $(\mathbf{4}, \mathbf{8})$. The most significant increase in haemolytic activity was observed with the esterified saponin 10a, which became the most active one, with an $\mathrm{HD}_{50}$ of $6.6 \mu \mathrm{M}$. In contrast, we observed that cytotoxicity is generally reduced after esterification except for saponins $\mathbf{3 a}$ and $\mathbf{7 a}$ with a $\beta$-L-arabinose and saponin 10a ( $\beta$-D-Glc- $(1 \rightarrow 2)-\alpha$-L-Ara) (Fig. 5 and 6$)$. This increase is very significant for saponins 3a and 10a which were only slightly cytotoxic in their carboxylic acid forms (Fig. 5 and 6). A similar, albeit moderate, increase of cytotoxic activity was observed with glucose containing saponins $\mathbf{1 4 a}, \mathbf{1 5 a}$ and $\mathbf{1 6 a}$ characterized by a $(1 \rightarrow 4)$ interglycosidic linkage (Table 1). Esterification did not affect the activity of $\alpha$-hederin (2a), which remained the most 
cytotoxic compound, whereas in the case of the haemolytic activity, 2a is twice as active as $\alpha-$ hederin (2).

In contrast to the free carboxylic acid saponins, no correlation between haemolytic and cytotoxic activities was observed with esterified ones. The methyl ester of $\delta$-hederin (1a) was one of the three most haemolytic saponins (1a, 2a, 10a) (Fig. 4), whereas with an $\mathrm{IC}_{50}$ of 14.3 $\mu \mathrm{M}$ 1a was among the least active of the compounds tested (Fig. 6). The order of activity with respect to the attached glycoside chain was different when comparing cytotoxic activity on $\mathrm{KB}$ cells $\left(\mathrm{IC}_{50}\right)$ and haemolytic activity $\left(\mathrm{HD}_{50}\right)$ for the esterified saponins 2a-13a (Fig. 4 and 6), and was not identical to that of their corresponding free acid counterparts (2-13). The order of haemolytic activity was a $(1 \rightarrow 2)>(1 \rightarrow 4)>(1 \rightarrow 3)$ linkage for an $\alpha$-L-rhamnopyranose or a $\beta$-D-glucopyranose, and a $(1 \rightarrow 2)>(1 \rightarrow 3)>(1 \rightarrow 4)$ linkage for a $\beta$-D-xylopyranose. It seems that for these esterified saponins, the $(1 \rightarrow 2)$ interglycosidic linkage is favoured for haemolytic activity. For cytotoxic activity, a $\beta$-D-glucopyranose was more efficient in the order of a $(1 \rightarrow 4)>(1 \rightarrow 2)>(1 \rightarrow 3)$ linkage. For an $\alpha$-L-rhamnopyranose and a $\beta$-D-xylopyranose a $(1 \rightarrow 2)$ linkage was the most cytotoxic. The respective order of activity of these two series was a $(1 \rightarrow 2)>(1 \rightarrow 3)>(1 \rightarrow 4)$ linkage for an $\alpha$-L-rhamnopyranose and a $(1 \rightarrow 2)>(1 \rightarrow 4)>$ $(1 \rightarrow 3)$ linkage for a $\beta$-D-xylopyranose.

The principal goal of the nuclear analysis was to identify the occurence of cell death through apoptosis. Four parameters were studied, percentage of mitosis and apoptosis, mean nuclear diameter and nuclear structure. Percentage of apoptosis does not reflect the true percentage of cells which undergo a death process because the final step of the mechanism is the detachment of the cells from the glass slide. As a consequence, a high percentage of apoptotic cells was not necessarily the expression of a wide phenomenon involving all the cells. It may well be the expression of a slow process which allowed us to detect cells which were in the intermediate steps of the apoptotic phenomenon; these cells exhibited a longer cell 
cycle than control cells. If this is the case, the result is more the consequence of a cytotostatic effect of the tested product than a pure cytotoxic one. This was corroborated by the drug concentrations tested, just below $\mathrm{IC}_{50}$ values.

Control cells showed a homogenous population with a typical chromatin organization and lacked mitosis, apoptosis and necrosis that is always the case in the culture conditions for $\mathrm{KB}$ cells [39]. The different saponins tested induced various modifications in nuclear structure and cell development (percentage of mitosis and apoptosis). $\delta$-Hederin (1) lead to nuclei enlargement (Fig. 7B) in association with low apoptosis $(1 \%)$ and mitosis $(<1 \%)$ (Table 2), which revealed a cytostatic effect. With the most efficient saponin $(2)\left(\mathrm{IC}_{50}=5.5 \mu \mathrm{M}\right)$ true apoptotic figures were not observed. Nuclei modifications implicated the condensation of chromatin, thus constituting an intermediate step in the apoptotic pathway (Fig. 7D). As the $\mathrm{IC}_{50}$ was very low, it could be hypothesized that the true apoptotic cells had been previously detached from the glass slide. Cell membrane lysis, which could be responsible for cell death, was not obvious as no cells ghosts were identified in these conditions.

Saponin 3, with a $\beta$-L-arabinose linkage, demonstrated low haemolytic and cytotoxic activities. Numerous apoptotic nuclei were detected in association with very high percentage of mitosis. The other nuclei appeared unmodified. This could be the result of a slow start of the apoptotic process, in which the selected cells were in a peculiar phase of the cell cycle and/or were not in a terminal phase at the time of smear preparation. As mitosis was still present, this saponin exerted a more cytostatic action then a purely rapid and cytotoxic one. An analogous response was obtained with saponin $\mathbf{1 0 .}$

Change in the interglycosidic linkage $(1 \rightarrow 3)$ to $(1 \rightarrow 4)(4$ and 5$)$ in the same rhamnose series lead to a lack of mitosis and apoptosis for $\mathbf{5}$ compared to $\mathbf{4}$. Saponin $\mathbf{5}$ was also less haemolytic than saponin $\mathbf{4}$ and not cytotoxic for KB cells considering MTT test and nuclei 
structure. On the other hand, saponin $\mathbf{4}$ showed a cytostatic action and could initiate apoptotic cell death.

A change in the second sugar, xylose $(\mathbf{6})$ or glucose $(\mathbf{1 0})$ with a $(1 \rightarrow 2)$ interglycosidic linkage, lead to a low level of mitosis, analogous to that of $\alpha$-hederin (2). Apoptosis was higher for saponin $10(4 \%)$ compared to saponins 6 and 2. Change in the interglycosidic linkage $(1 \rightarrow 2)(\mathbf{6})$ and $(1 \rightarrow 3)(\mathbf{8})$ of $\beta$-D-xylose/ $\alpha$-L-arabinose saponins did not significantly modify the $\mathrm{HD}_{50}$, the $\mathrm{IC}_{50}$, or the observed nuclear structures (Fig. 3, 5 and 7K). This could be considered as the expression of a predominant cytostatic process. The presence of apoptosis could be the consequence of the slow rate of the apoptotic process, preservating the rapid detachment of the cells from the glass slides. At the higher concentration, cells disappeared from the glass slides $(\mathbf{8})$, in correlation with the haemolytic activity which altered the cell membrane.

Saponin esterification, which increased all of the $\mathrm{IC}_{50}$ values except for saponin $\mathbf{2 a}$, allowed intermediate (1a, 2a) or typical apoptotic figures (3a). Esterified saponins $6 \mathbf{a}, \mathbf{8 a}$, 10a, and 13a lead to total detachment of the cells from the glass slides. Among these molecules, $\mathrm{IC}_{50}$ values were high $(\geq 9.5 \mu \mathrm{M})$ to undetectable, while $\mathrm{HD}_{50}$ values were low. In these cases, the lethal action could be correlated to the haemolytic activity that altered the cell membrane, inducing cell detachment [28]. This hypothesis was corroborated by the differential re-organization of intrinsic proteins which is dependent on the ability of the saponins to integrate into the membrane $[25,37,40]$. Clearly, cell death occurred rapidly and systematically for all of the cells. Necrosis can not be completely excluded, but such cell alterations were not observed.

In conclusion, structure-activity relationships have been established for both the haemolytic and cytotoxic activities of 19 synthesized free carboxylic acid and methyl ester 
saponins. It is clear that the sugar chain as a whole, e.g. the configuration of the interglycosidic linkages, the substitution pattern, and the type of sugar units involved, has an undeniable influence on the rate of both haemolytic and cytotoxic activity. The same glycoside chain can also have a different influence when the aglycone is only slightly modified (carboxylic acid or methyl ester). The hydrophobic aglycone backbone could probably intercalate into the hydrophobic membrane bilayer, while the glycoside chain could interact with the polar group. Multiple interactions of this sort would thus interfere with the membrane fluidity [38]. The methyl ester saponins were generally more haemolytic and less cytotoxic than their corresponding free carboxylic acids. This suggests that esterification, which increases the lipophilicity of the triterpene moiety, could create a different interaction with the cell membrane. Moreover, the presence of free carboxylic acid at C-28 seems to be essential for cytotoxicity as previously observed [41].

In this study, the anomeric configurations $\beta$-L or $\alpha$-D were unfavourable, suggesting that these configurations were not recognised by the cellular constituents. $\alpha$-Hederin (2) was clearly the most haemolytic and cytotoxic saponin, thus confirming the fact that the $\alpha$-L-Rhap$(1 \rightarrow 2)$ - $\alpha$-L-Arap osidic chain was important for cytotoxic activity as previously postulated [21, 41]. Unfortunately, for the $\alpha$-L-arabinose free carboxylic acid saponins (3-13), none of the three sugars used in this study (L-rhamnose, D-xylose ou D-glucose) simultaneously increased both haemolytic and cytotoxic activity, whatever the position of substitution on the $\alpha$-L-arabinose. Each sugar showed, however, a preferential substitution position on the $\alpha$-Larabinopyranose for good activity. Esterification in position 28 increased haemolytic activity and decreased cytotoxic activity in the majority of cases. Thus, it is impossible to correlate haemolytic activity and cytotoxic activity within this group of compounds.

The cell responses pointed out that the different saponins might block the cell cycle at different steps [42] and / or that the mechanisms were initiated with varied delay. The 
resulting cytotoxicity, as revealed by biological tests and nuclei structure, reveals the duality and/or complementarity of a plasma membrane alteration and the action on membrane receptors for apoptosis. It has been recently pointed out that the triterpenoid saponin avicin can induce apoptosis through the formation of channels within the cell membrane [43]. It could also be hypothesized that these alterations of the cell membrane could interfere with the underlying cytoskeleton and more precisely with the hemi-desmosomes which participate in cell adhesion to the substrate. The lack of cells after the addition of some saponins could thus be the result of a multiple mode of action. Here we have shown that nuclear events, such as apoptosis, are involved in the cytotoxicity of saponins, and a detailed mechanistic study is necessary to better understand this phenomenon.

\section{Acknowledgements}

The authors would like to thank the CNRS (Centre National de Recherche Scientifique) and the French Research Ministry for financial support as well as the Ph. D. scholarship for MC.

\section{References and Notes}

[1] K. Hostettmann, A. Marston, Saponins. Chemistry and Pharmacology of Natural Products, Cambridge University Press, Cambridge, 1995.

[2] R. Segal, I. Milo-Goldzweig, The susceptibility of cholesterol-depleted erythrocytes to saponin and sapogenin hemolysis, Biochim. Biophys. Acta 512 (1978) 223-226. 
[3] T. Nakamura, K. Inoue, S. Nojima, U. Sankawa, J. Shoji, T. Kawasaki, et al., Interaction of saponins with red blood cells as well as with the phosphatidylcholine liposomal membranes, J. Pharm. Dyn. 2 (1979) 374-382.

[4] P. Seeman, Ultrastructure of membrane lesions in immune lysis, osmotic lysis and druginduced lysis, Fed. Proc. 33 (1974) 2116-2124.

[5] A.M. Glauert, J.T. Dingle, J.A. Lucy, Action of saponin on biological cell membranes, Nature 8 (1962) 953-955.

[6] E. Schlösser, G. Wulff, Uber die strukturspezifität der saponinhämolyse. I: Triterpensaponine und -aglykone, Z. Naturforschg. 24b (1969) 1284-1290.

[7] L. Voutquenne, C. Lavaud, G. Massiot, L. Le Men-Olivier, Structure-activity relationships of haemolytic saponins, Pharmaceutical Biol. 40 (2002) 253-262.

[8] M. Chwalek, K. Plé, L. Voutquenne-Nazabadioko, Synthesis and hemolytic activity of some hederagenin diglycosides, Chem. Pharm. Bull. 52 (2004) 965-971.

[9] M. Takechi, C. Uno, Y. Tanaka, Structure-activity relationships of synthetic saponins, Phytochemistry 41 (1996) 121-123.

[10] K. Oda, H. Matsuda, T. Murakami, S. Katayama, T. Ohgitani, M. Yoshikawa, Adjuvant and haemolytic activities of 47 saponins derived from medicinal and food plants, J. Biol. Chem. 381 (2000) 67-74.

[11] W. Seebacher, E. Haslinger, K. Rauchensteiner, J. Jurenitsch, A. Presser, R. Weis, Synthesis and haemolytic activity of randianin isomers, Monatsh. Chem. 130 (1999) 887897.

[12] W. Seebacher, R. Weis, J. Jurenitsch, K. Rauchensteiner, E. Haslinger, Synthesis and haemolytic activity of oleanolic acid trisaccharides, Monatsh. Chem. 130 (1999) 13831391. 
[13] W. Seebacher, R. Weis, J. Jurenitsch, K. Rauchensteiner, E. Haslinger, Synthesis and hemolytic properties of arvensoside B isomers, Monatsh. Chem. 131 (2000) 985-996.

[14] M. Takechi, Y. Tanaka, Structure-activity relationships of synthetic methyl oleanolate glycosides, Phytochemistry 31 (1992) 3789-3791.

[15] N. Ullah, W. Seebacher, R. Weis, J. Jurenitsch, K. Rauchensteiner, E. Haslinger, Synthesis and hemolytic properties of glycyrrhetic acid glycosides, Monatsh. Chem. 131 (2000) 787-794.

[16] R. Segal, I. Milo-Goldzweig, H. Schupper, D.V. Zaitschek, Effect of ester groups on the haemolytic action of sapogenins-II: esterification with bifunctional acids, Biochem. Pharmacol. 19 (1970) 2501-2507.

[17] R. Higuchi, T. Kawasaki, Pericarp saponins of Akebia quinata DeCNE. I. Glycosides of hederagenin and oleanolic acid, Chem. Pharm. Bull. 24 (1976) 1021-1032.

[18] K. Hostettmann, Saponins with molluscicidal activity from Hedera helix L, Helv. Chim. Acta 63 (1980) 606-609.

[19] H. Kawai, M. Kuroyanagi, K. Umehara, A. Ueno, M. Satake, Studies on the saponins of Lonicera japonica THUNB, Chem. Pharm. Bull. 36 (1988) 4769-4775.

[20] N. Gopalsamy, J. Gueho, H.R. Julien, A.W. Owadally, K. Hostettmann, Molluscicidal saponins of Polyscias dichroostachya, Phytochemistry 29 (1990) 793-795.

[21] H.-J. Park, S.-H. Kwon, J.-H. Lee, K.-H. Lee, K. Miyamoto, K.-T. Lee, Kalopanaxsaponin A is a basic saponin structure for the anti-tumor activity of hederagenin monodesmosides, Planta Med. 67 (2001) 118-121.

[22] C. Barthomeuf, E. Debiton, V. Mshvildadze, E. Kemertelidze, G. Balansard, In vitro activity of hederacolchisid $\mathrm{A}_{1}$ compared with other saponins from Hedera colchica against proliferation of human carcinoma and melanoma cells, Planta Med. 68 (2002) 672-675. 
[23] J. Quetin-Leclercq, R. Elias, G. Balansard, R. Bassler, L. Angenot, Cytotoxic activity of some triterpenoid saponins, Planta Med. 58 (1992) 279-281.

[24] H.-J. Jung, C.O. Lee, K.-T. Lee, J. Choi, H.-J. Park, Structure-activity relationship of oleanane disaccharides isolated from Akebia quinata versus cytotoxicity against cancer cells and NO inhibition, Biol. Pharm. Bull. 27 (2004) 744-747.

[25] S. Danloy, J. Quetin-leclercq, P. Coucke, M.C. De Pauw-Gillet, R. Elias, G. Balansard, et al., Effects of $\alpha$-hederin, a saponin extracted from Hedera helix, on cells cultured in vitro, Planta Med. 60 (1994) 45-49.

[26] Y. Mimaki, M. Kuroda, T. Asano, Y. Sashida, Triterpene saponins and lignans from the roots of Pulsatilla chinensis and their cytotoxic activity against HL-60 cells, J. Nat. Prod. 62 (1999) 1279-1283.

[27] K.-T. Lee, I.-C. Sohn, H.-J. Park, D.-W. Kim, G.-O. Jung, K.-Y. Park, Essential moiety for antimutagenic and cytotoxic activity of hederagenin monodesmosides and bidesmosides isolated from the stem bark of Kalopanax pictus, Planta Med. 66 (2000) 329-332.

[28] S. Rooney, M.F. Ryan, Effects of $\alpha$-hederin and thymoquinone, constituents of Nigella sativa, on Human cancer cell lines, Anticancer Res. 25 (2005) 2199-2204.

[29] S.S. Muthu Kumara, B.T. Kwong Huat, Extraction, isolation and characterisation of antitumor principle, $\alpha$-hederin, from the seeds of Nigella sativa, Planta Med. 67 (2001) 29-32.

[30] G. Bader, B. Plohmann, K. Hiller, G. Franz, Cytotoxicity of triterpenoid saponins. Part 1 : activities against tumor cells in vitro and hemolytical index, Pharmazie 51 (1996) 414417.

[31] K. Plé, M. Chwalek, L. Voutquenne-Nazabadioko, Synthesis of $\alpha$-hederin, $\delta$-hederin, and related triterpenoid saponins, Eur. J. Org. Chem. (2004) 1588-1603. 
[32] K. Plé, M. Chwalek, L. Voutquenne-Nazabadioko, Synthesis of L-arabinopyranose containing hederagenin saponins, Tetrahedron 61 (2005) 4347-4362.

[33] E. Schlösser, Interaction of saponins with cholesterol, lecithin and albumin, Can. J. Physiol. Pharmacol. 47 (1969) 487-490.

[34] M.C. Jacob, M. Favre, J.C., Bensa Membrane cell permeabilization with saponin and multiparametric analysis by flow cytometry, Cytometry 12 (1991) 550-558.

[35] M. Takechi, Y. Tanaka, Haemolytic time course differences between steroid and triterpenoid saponins, Planta Med. 61 (1995) 76-77.

[36] M. Haruma, M. Tanaka, T. Sugimoto, R. Kojima, Y. Suzuki, T. Konoshima, et al., Alteration of $\mathrm{Na}^{+}$Permeability in Human Erythrocytes as Studied by ${ }^{23} \mathrm{Na}-\mathrm{NMR}$ and Inhibition of the Kidney $\mathrm{Na}^{+}, \mathrm{K}^{+}$-ATPase Activities with Saponins: Interaction of Gleditsia Saponins with Human Erythrocyte Membranes, Bioorg. Med. Chem. Lett. 5/8 (1995) 827-830.

[37] E. Baumann, G. Stoya, A. Völkner, W. Richter, C. Lemke, W. Linss, Hemolysis of human erythrocytes with saponin affects the membrane structure, Acta Histochem. 102 (2000) 21-35.

[38] G. Francis, Z. Kerem, H. P.S. Makkar, K. Becker, The biological action of saponins in animal systems: a review, Brit. J. Nutr. 88 (2002) 587-605.

[39] E. Elias, N. Lalun, M. Lorenzato, L. Blache, P. Chelidze, M.-F. O’Donohue, D. Ploton, H. Bobichon, Cell-cycle-dependent three-dimensional redistribution of nuclear proteins, P120, pKi-67, and SC 35 splicing factor, in the presence of the topoisomerase I inhibitor camptothecin, Exp. Cell Res. 291 (2003) 176-188.

[40] M.F. Melzig, G. Bader, R. Loose, Investigations of the mechanism of membrane activity of selected triterpenoid saponins, Planta Med. 67 (2001) 43-48. 
[41] S.-C. Bang, J.-H. Lee, G.-H. Kim, M.-Y. Yoon, B.-Z. Ahn, Antitumor activity of Pulsatilla koreana saponins and their structure-activity relationship, Chem. Pharma. Bull. 53 (2005) 1451-1454.

[42] P. Trouillas, C. Corbière, B. Liagre, J.-L. Duroux, J.-L. Beneytout, Structure-function relationship for saponin effects on cell cycle arrest and apoptosis in the human 1547 osteosarcoma cells: a molecular modelling approach of natural molecules structurally close to diosgenin, Bioorg. Med. Chem. 13 (2005) 1141-1149.

[43] X.X. Li, B. Davis, V. Haridas, J.U. Gutterman, M. Colombini, Proapoptotic triterpene electrophiles (Avicins) form channels in membranes : cholesterol dependence. Biophys. J. 88 (2005) 2577-2584. 


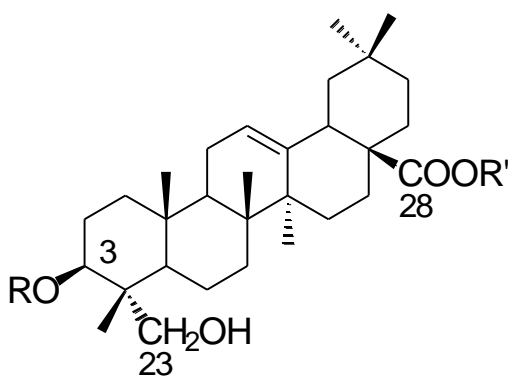

$$
\begin{aligned}
& \mathrm{R}=\alpha-\mathrm{L}-\text { Ara } \quad \mathrm{R}^{\prime}=\mathrm{H}(\mathbf{1}) \\
& \mathrm{R}^{\prime}=\mathrm{CH}_{3}(\mathbf{1 a}) \\
& \mathrm{R}=\alpha \text {-L-Rha- }(1 \rightarrow 2)-\alpha-\mathrm{L}-\mathrm{Ara} \quad \mathrm{R}^{\prime}=\mathrm{H}(\mathbf{2}) \\
& \mathrm{R}^{\prime}=\mathrm{CH}_{3}(\mathbf{2 a}) \\
& \mathrm{R}=\alpha-\mathrm{L}-\mathrm{Rha}-(1 \rightarrow 2)-\beta-\mathrm{L}-\mathrm{Ara} \quad \mathrm{R}^{\prime}=\mathrm{H}(\mathbf{3}) \\
& \mathrm{R}^{\prime}=\mathrm{CH}_{3}(\mathbf{3 a}) \\
& \mathrm{R}=\alpha-\mathrm{L}-\mathrm{Rha}-(1 \rightarrow 3)-\alpha-\mathrm{L}-\mathrm{Ara} \quad \mathrm{R}^{\prime}=\mathrm{H}(\mathbf{4}) \\
& \mathrm{R}^{\prime}=\mathrm{CH}_{3}(\mathbf{4 a}) \\
& \mathrm{R}=\alpha-\mathrm{L}-\mathrm{Rha}-(1 \rightarrow 4)-\alpha-\mathrm{L}-\text { Ara } \quad \mathrm{R}^{\prime}=\mathrm{H}(\mathbf{5}) \\
& \mathrm{R}^{\prime}=\mathrm{CH}_{3}(\mathbf{5 a})
\end{aligned}
$$

$$
\begin{array}{llll}
\mathrm{R}=\beta-\mathrm{D}-\mathrm{Xyl}-(1 \rightarrow 2)-\alpha-\mathrm{L}-\mathrm{Ara} & \mathrm{R}^{\prime}=\mathrm{H}(\mathbf{6}) & \mathrm{R}=\beta-\mathrm{D}-\mathrm{Glc}-(1 \rightarrow 2)-\alpha-\mathrm{L}-\mathrm{Ara} & \mathrm{R}^{\prime}=\mathrm{H}(\mathbf{1 0}) \\
& \mathrm{R}^{\prime}=\mathrm{CH}_{3}(\mathbf{6 a}) & & \mathrm{R}^{\prime}=\mathrm{CH}_{3}(\mathbf{1 0 a}) \\
\mathrm{R}=\beta-\mathrm{D}-\mathrm{Xyl}-(1 \rightarrow 2)-\beta-\mathrm{L}-\mathrm{Ara} & \mathrm{R}^{\prime}=\mathrm{H}(\mathbf{7}) & \mathrm{R}=\beta-\mathrm{D}-\mathrm{Glc}-(1 \rightarrow 2)-\beta-\mathrm{L}-\mathrm{Ara} & \mathrm{R}^{\prime}=\mathrm{H}(\mathbf{1 1}) \\
& \mathrm{R}^{\prime}=\mathrm{CH}_{3}(\mathbf{7 a}) & & \mathrm{R}^{\prime}=\mathrm{CH}_{3}(\mathbf{1 1 a}) \\
\mathrm{R}=\beta-\mathrm{D}-\mathrm{Xyl}-(1 \rightarrow 3)-\alpha-\mathrm{L}-\mathrm{Ara} & \mathrm{R}^{\prime}=\mathrm{H}(\mathbf{8}) & \mathrm{R}=\beta-\mathrm{D}-\mathrm{Glc}-(1 \rightarrow 3)-\alpha-\mathrm{L}-\mathrm{Ara} & \mathrm{R}^{\prime}=\mathrm{H}(\mathbf{1 2}) \\
& \mathrm{R}^{\prime}=\mathrm{CH}_{3}(\mathbf{8 a}) & & \mathrm{R}^{\prime}=\mathrm{CH}_{3}(\mathbf{1 2 a}) \\
\mathrm{R}=\beta-\mathrm{D}-\mathrm{Xyl}-(1 \rightarrow 4)-\alpha-\mathrm{L}-\mathrm{Ara} a & \mathrm{R}^{\prime}=\mathrm{H}(\mathbf{9}) & \mathrm{R}=\beta-\mathrm{D}-\mathrm{Glc}-(1 \rightarrow 4)-\alpha-\mathrm{L}-\mathrm{Ara} & \mathrm{R}^{\prime}=\mathrm{H}(\mathbf{1 3}) \\
& \mathrm{R}^{\prime}=\mathrm{CH}_{3}(\mathbf{9 a}) & & \mathrm{R}^{\prime}=\mathrm{CH}_{3}(\mathbf{1 3 a})
\end{array}
$$

Fig. 1. $\alpha$-L-Rha-L-Ara, $\beta$-D-Xyl-L-Ara and $\beta$-D-Glc-L-Ara hederagenin saponins

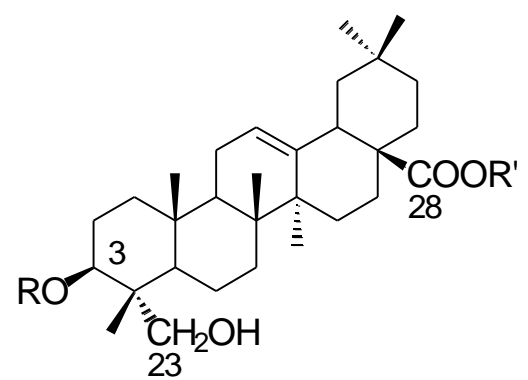

$$
\begin{array}{lll}
\mathrm{R}=\beta-\mathrm{D}-\mathrm{Glc}-(1 \rightarrow 4)-\beta-\mathrm{D}-\mathrm{Glc} & \text { (cellobiosyl) } & \mathrm{R}^{\prime}=\mathrm{H}(\mathbf{1 4}) \\
& & \mathrm{R}^{\prime}=\mathrm{CH}_{3}(\mathbf{1 4 a}) \\
\mathrm{R}=\beta-\mathrm{D}-\mathrm{Gal}-(1 \rightarrow 4)-\beta-\mathrm{D}-\mathrm{Glc} & (\text { lactosyl }) & \mathrm{R}^{\prime}=\mathrm{H}(\mathbf{1 5}) \\
& & \mathrm{R}^{\prime}=\mathrm{CH}_{3}(\mathbf{1 5 a}) \\
\mathrm{R}=\alpha-\mathrm{D}-\mathrm{Glc}-(1 \rightarrow 4)-\beta-\mathrm{D}-\mathrm{Glc} & (\text { maltosyl) } & \mathrm{R}^{\prime}=\mathrm{H}(\mathbf{1 6}) \\
& & \mathrm{R}^{\prime}=\mathrm{CH}_{3}(\mathbf{1 6 a}) \\
\mathrm{R}=\beta-\mathrm{D}-\mathrm{Glc}-(1 \rightarrow 6)-\beta-\mathrm{D}-\mathrm{Glc} & (\text { gentiobiosyl) } & \mathrm{R}^{\prime}=\mathrm{H}(\mathbf{1 7}) \\
& & \mathrm{R}^{\prime}=\mathrm{CH}_{3}(\mathbf{1 7 a}) \\
\mathrm{R}=\alpha-\mathrm{D}-\mathrm{Glc}-(1 \rightarrow 6)-\beta-\mathrm{D}-\mathrm{Glc} & (\text { isomaltosyl) } & \mathrm{R}^{\prime}=\mathrm{H}(\mathbf{1 8}) \\
& & \mathrm{R}^{\prime}=\mathrm{CH}_{3}(\mathbf{1 8 a}) \\
\mathrm{R}=\alpha-\mathrm{D}-\mathrm{Gal}-(1 \rightarrow 6)-\beta-\mathrm{D}-\mathrm{Glc} & \text { (melibiosyl) } & \mathrm{R}^{\prime}=\mathrm{H}(\mathbf{1 9}) \\
& & \mathrm{R}^{\prime}=\mathrm{CH}_{3}(\mathbf{1 9 a})
\end{array}
$$

Fig. 2. Glucose containing hederagenin saponins 


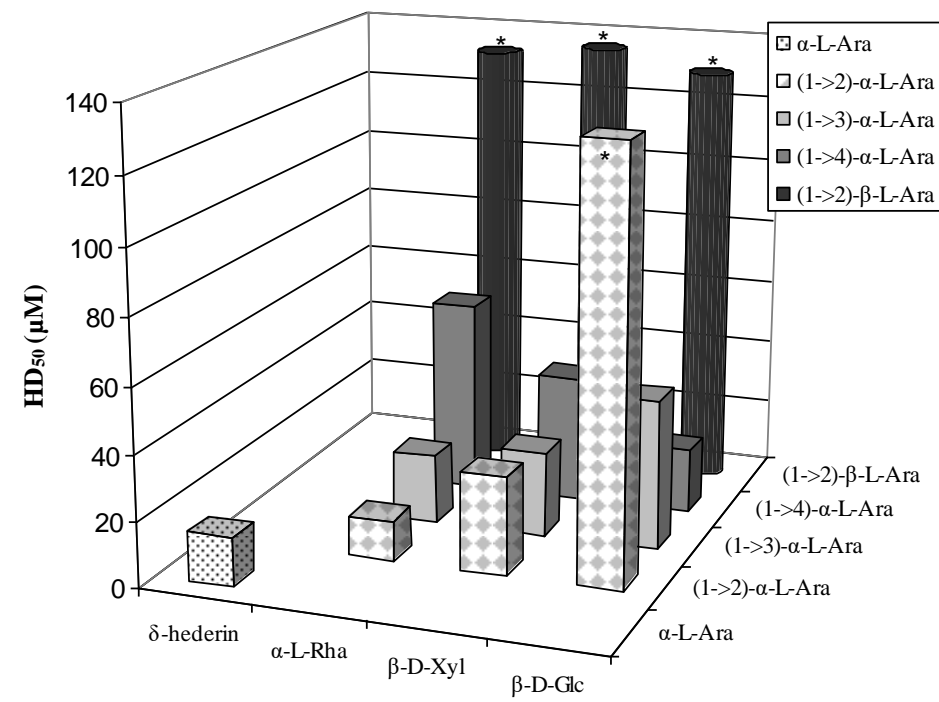

*: no haemolytic activity observed at this concentration

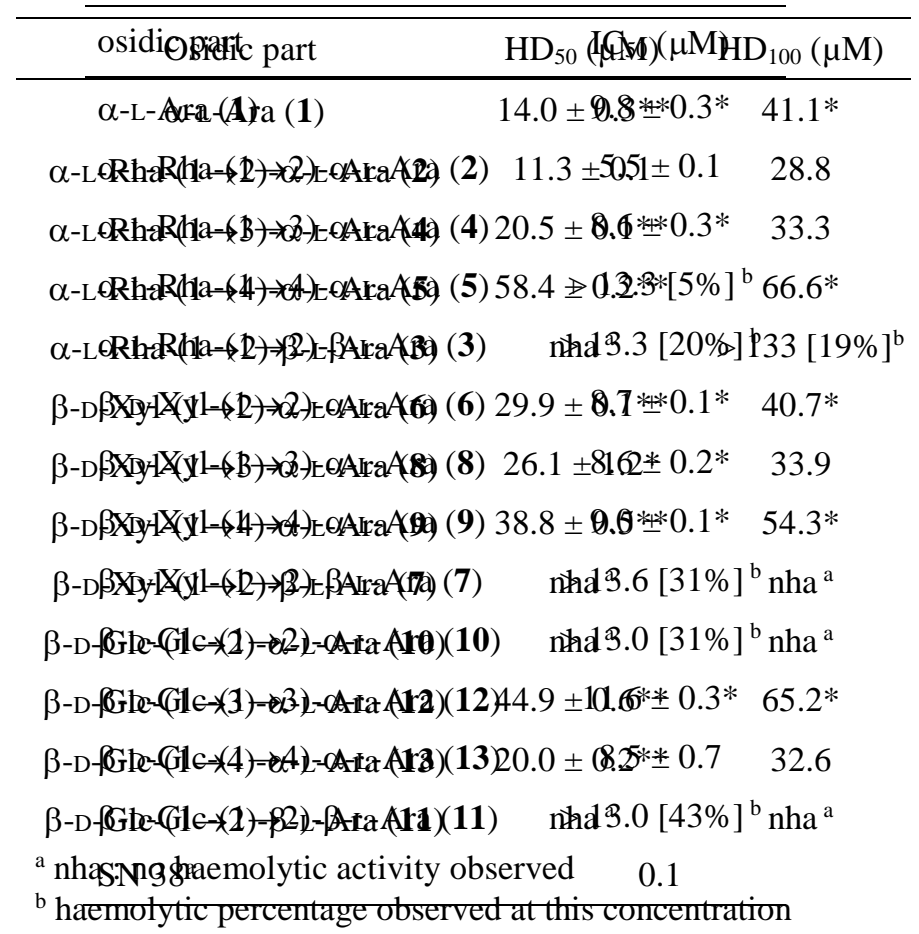

Fig. 3. Comparative haemolytic activity of L-arabinose containing hederagenin saponins (113). Each value represents means \pm standard errors of triplicate tests. Significance difference of each saponin was calculated compared to $\alpha$-hederin (2) using Student T-test, $* P<0.01$, and $* * P<0.001$

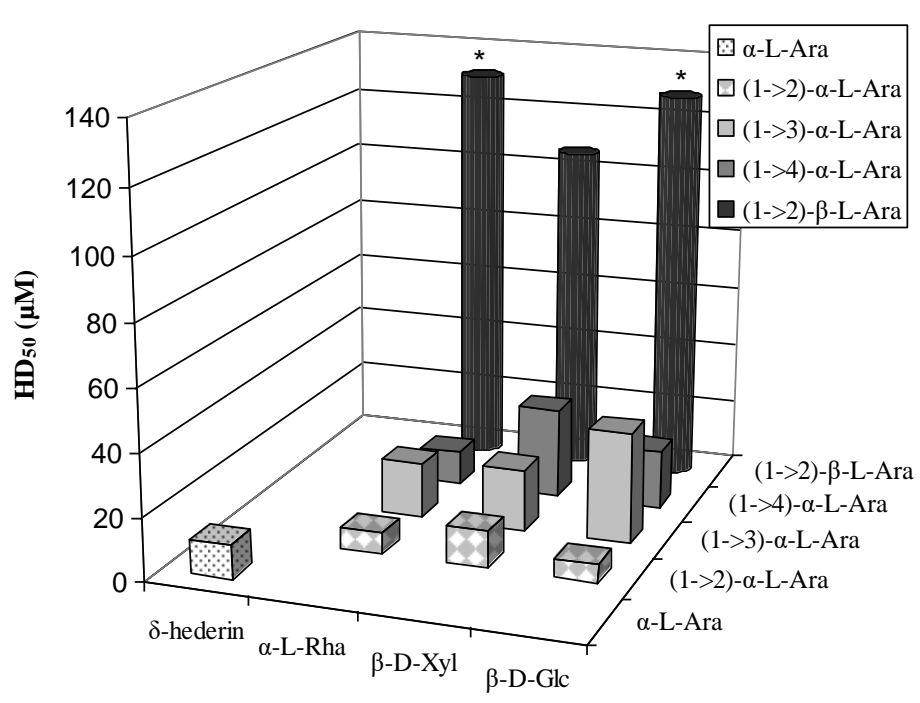

*: no haemolytic activity observed at this concentration

\begin{tabular}{|c|c|c|}
\hline Osidic part & $\mathrm{HD}_{50}(\mu \mathrm{M})$ & $\mathrm{HD}_{100}(\mu \mathrm{M})$ \\
\hline$\alpha$-L-Ara (1a) & $11.0 \pm 0.2 * *$ & $16.1 *$ \\
\hline$\alpha-L-R h a-(1 \rightarrow 2)-\alpha-L-A r a(2 a)$ & $6.8 \pm 0.3$ & 13.1 \\
\hline$\alpha$-L-Rha- $(1 \rightarrow 3)-\alpha-L-A r a(4 a)$ & $18.3 \pm 1.7 *$ & $39.2 * *$ \\
\hline$\alpha$-L-Rha- $(1 \rightarrow 4)-\alpha-L-A r a(5 \mathbf{a})$ & $11.0 \pm 0.2 * *$ & $26.1 * *$ \\
\hline$\alpha$-L-Rha- $(1 \rightarrow 2)-\beta$-L-Ara (3a) & nha $^{\mathrm{a}}$ & $>131[37 \%]^{\mathrm{b}}$ \\
\hline$\beta-\mathrm{-}-\mathrm{Xyl}-(1 \rightarrow 2)-\alpha-\mathrm{L}-\operatorname{Ara}(\mathbf{6 a})$ & $11.8 \pm 0.1 * *$ & $26.6 * *$ \\
\hline$\beta$-D-Xyl- $(1 \rightarrow 3)-\alpha-L-A r a(\mathbf{8 a})$ & $21.1 \pm 0.4^{* *}$ & $33.3 * *$ \\
\hline$\beta$-D-Xyl- $(1 \rightarrow 4)-\alpha-L-A r a(9 a)$ & $29.6 \pm 0.5^{* *}$ & $39.9 *$ \\
\hline$\beta$-D-Xyl- $(1 \rightarrow 2)-\beta-\mathrm{L}-\mathrm{Ara}(\mathbf{7 a})$ & $108.2 \pm 3.1 * *$ & $133.2 * *$ \\
\hline$\beta$-D-Glc- $(1 \rightarrow 2)-\alpha-\mathrm{L}-\operatorname{Ara}(\mathbf{1 0 a})$ & $6.6 \pm 0.2$ & 10.7 \\
\hline$\beta$-D-Glc- $(1 \rightarrow 3)-\alpha-L-A r a(12 \mathbf{a})$ & $35.0 \pm 0.4^{* *}$ & $51.2 * *$ \\
\hline$\beta$-D-Glc- $(1 \rightarrow 4)-\alpha-L-A r a(13 a)$ & $18.8 \pm 0.2 * *$ & $25.6^{*}$ \\
\hline$\beta$-D-Glc- $(1 \rightarrow 2)-\beta$-L-Ara (11a) & nha $^{\mathrm{a}}$ & $>128[32 \%]^{\mathrm{b}}$ \\
\hline
\end{tabular}

Fig. 4. Comparative haemolytic activity of L-arabinose containing methyl hederagenate saponins (1a-13a). Each value represents means \pm standard errors of triplicate tests. Significance difference of each saponin was calculated compared to $\alpha$-hederin methyl ester (2a) using Student T-test, $* P<0.01$, and $* * P<0.001$. 


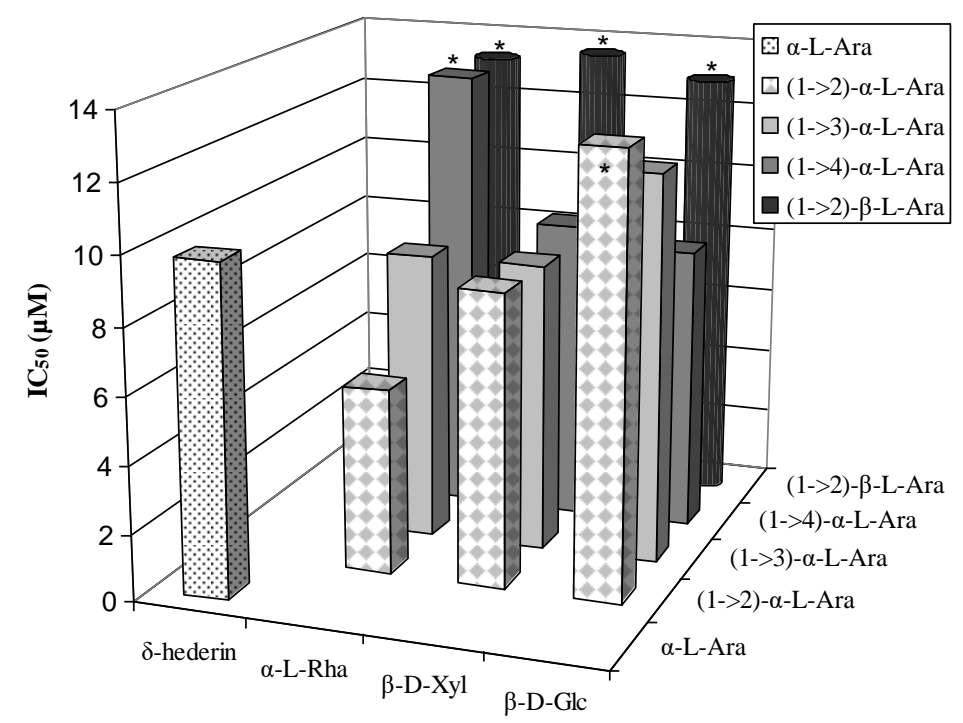

* : $\mathrm{IC}_{50}$ not observed at the highest concentration tested

${ }^{\mathrm{a}}$ value at $24 \mathrm{~h}$ in DMEM-10\%FCS culture medium

${ }^{\mathrm{b}}$ percentage of cell death observed at this concentration

Fig. 5. Effect of L-arabinose containing hederagenin saponin (1-13) on KB cells. Each value represents means \pm standard errors of triplicate cultures. Significance difference of each saponin was calculated compared to $\alpha$-hederin (2) using Student T-test, $* P<0.01$.

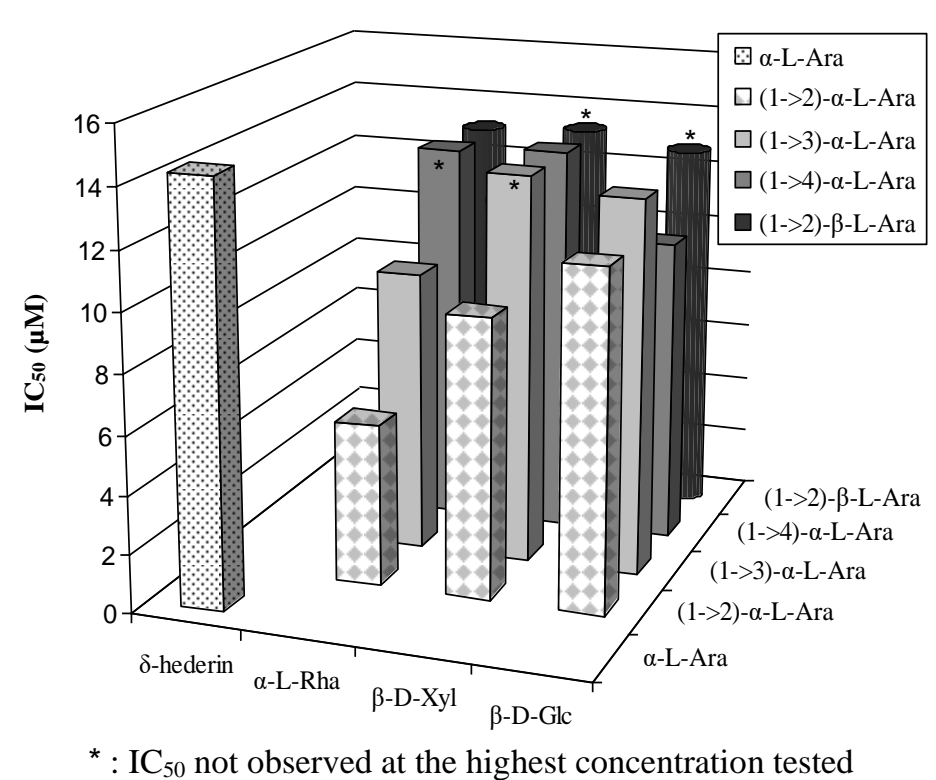

\begin{tabular}{|c|c|}
\hline osidic part & $\mathrm{IC}_{50}(\mu \mathrm{M})$ \\
\hline$\alpha-\mathrm{L}-\operatorname{Ara}(\mathbf{1 a})$ & $14.3 \pm 0.5^{*}$ \\
\hline$\alpha-L-R h a-(1 \rightarrow 2)-\alpha-L-A r a(\mathbf{2 a})$ & $5.5 \pm 0.2$ \\
\hline$\alpha-L-R h a-(1 \rightarrow 3)-\alpha-L-A r a(4 a)$ & $9.6 \pm 0.2 *$ \\
\hline$\alpha-L-R h a-(1 \rightarrow 4)-\alpha-L-\operatorname{Ara}(\mathbf{5 a})$ & $>13.1[20 \%]^{b}$ \\
\hline$\alpha$-L-Rha- $(1 \rightarrow 2)-\beta$-L-Ara (3a) & $13.1 \pm 0.3 *$ \\
\hline$\beta$-D-Xyl-(1 $(\rightarrow 2)-\alpha-L-A r a(6 a)$ & $9.5 \pm 0.6^{*}$ \\
\hline$\beta$-D-Xyl-( $1 \rightarrow 3)-\alpha-L-A r a(\mathbf{8 a})$ & $>13.3[25 \%]^{\mathrm{b}}$ \\
\hline$\beta$-D-Xyl-(1 $\rightarrow 4)-\alpha-L-A r a(9 a)$ & $13.3 \pm 0.1^{*}$ \\
\hline$\beta$-D-Xyl-( $1 \rightarrow 2)-\beta-\mathrm{L}-\operatorname{Ara}(\mathbf{7 a})$ & $>13.3[42 \%]^{b}$ \\
\hline$\beta$-D-Glc- $(1 \rightarrow 2)-\alpha-L-A r a(10 a)$ & $11.5 \pm 0.5 *$ \\
\hline$\beta$-D-Glc- $(1 \rightarrow 3)-\alpha-L-A r a(12 a)$ & $12.8 \pm 0.1 *$ \\
\hline$\beta$-D-Glc- $(1 \rightarrow 4)-\alpha-L-A r a(13 a)$ & $10.4 \pm 0.3 *$ \\
\hline$\beta$-D-Glc- $(1 \rightarrow 2)-\beta$-L-Ara (11a) & $>12.8[20 \%]^{\mathrm{b}}$ \\
\hline $\mathrm{SN} 38^{\mathrm{a}}$ & 0.1 \\
\hline
\end{tabular}

${ }^{\mathrm{a}}$ value at $24 \mathrm{~h}$ in DMEM-10\%FCS culture medium

${ }^{\mathrm{b}}$ percentage of cell death observed at this concentration

Fig. 6. Effect of L-arabinose containing methyl hederagenate saponin (1a-13a) on KB cells. Each value represents means \pm standard errors of triplicate cultures. Significance difference of each saponin was calculated compared to $\alpha$-hederin methyl ester (2a) using Student T-test, $* P<0.01$. 

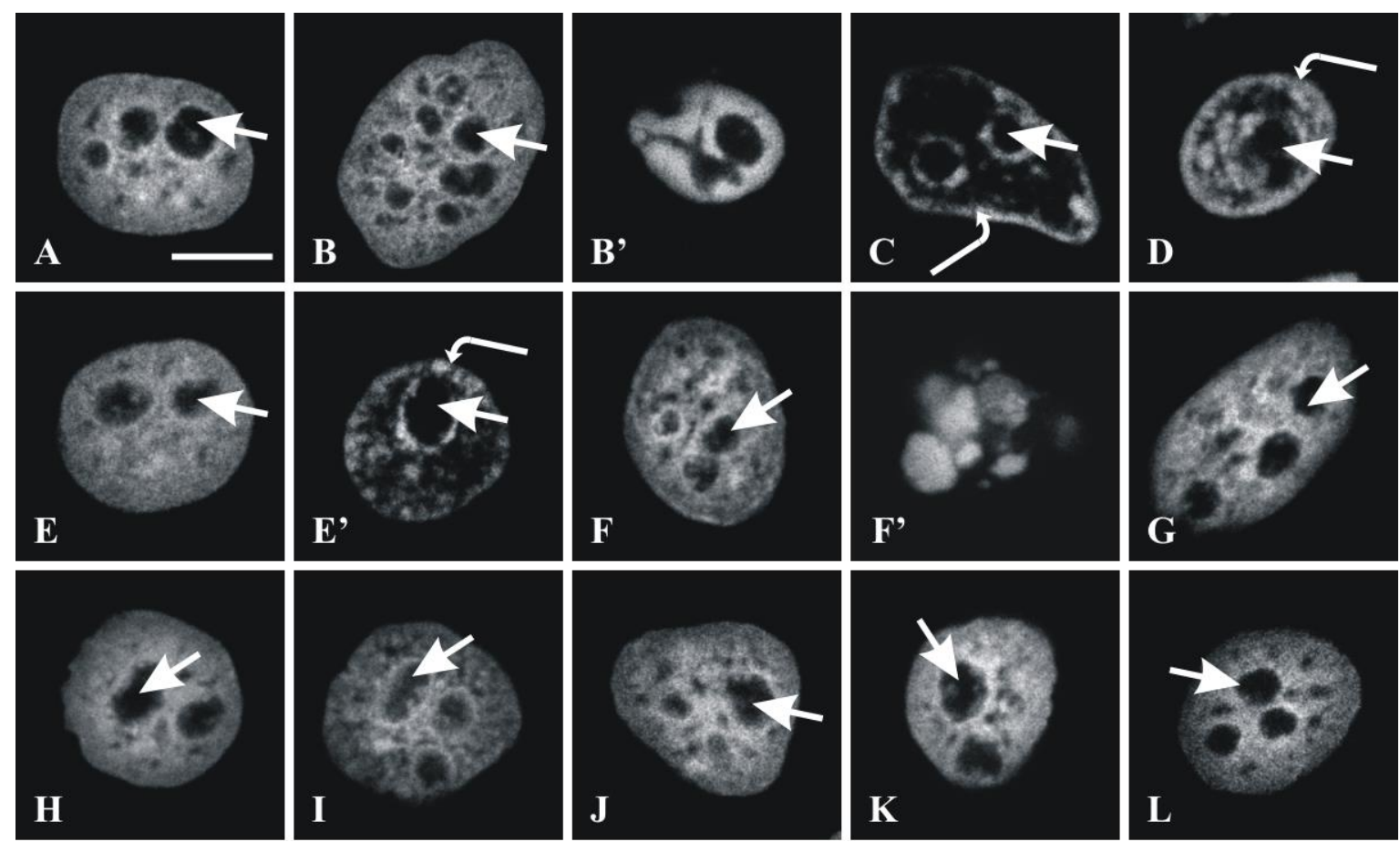

Fig. 7. Confocal analysis of nuclei after treatment with various saponins. (A) control cells. (B and B') saponin 1 at $8.3 \mu \mathrm{M}$. (C) saponin 1a at $12.1 \mu \mathrm{M}$. (D) saponin 2 at $6.7 \mu \mathrm{M}$. (E and E') saponin $2 \mathbf{a}$ at $3.3 \mu \mathrm{M}$. (F and F') saponin 3 at $10 \mu \mathrm{M}$. (G) saponin 3a at $9.8 \mu \mathrm{M}$. (H) saponin 4 at $6.7 \mu \mathrm{M}$. (I) saponin 5 at $13.3 \mu \mathrm{M}$. (J) saponin 6 at $6.8 \mu \mathrm{M}$. (K) saponin 8 at $6.8 \mu \mathrm{M}$. (L) saponin 13 at $6.5 \mu \mathrm{M}$. Chromatin condensation lining the nuclear envelope ( Nucleolus $(\leftarrow)$. Bar $=5 \mu \mathrm{m}$. (B) bar $=8 \mu \mathrm{m}$. 
Table 1.

Haemolytic ( $\mathrm{HD}_{50}$ and $\left.\mathrm{HD}_{100}\right)$ and cytotoxic activity $\left(\mathrm{IC}_{50}\right)$ of saponins (14-19) and their methyl ester (14a-19a) in $\mu \mathrm{M}$ (means \pm standard errors).

\begin{tabular}{|c|c|c|c|c|c|c|c|}
\hline Saponin & $\mathrm{HD}_{50}$ & $\mathrm{HD}_{100}$ & $\mathrm{IC}_{50}$ & Saponin & $\mathrm{HD}_{50}$ & $\mathrm{HD}_{100}$ & $\mathrm{IC}_{50}$ \\
\hline 14 (cellobiosyl) & $27.3 \pm 0.1 * *$ & 37.6 & $>12.5[16 \%]^{\mathrm{b}}$ & $14 a$ & $10.5 \pm 0.8^{* *}$ & $24.7^{*}$ & $12.3 \pm 0.6^{*}$ \\
\hline 15 (lactosyl) & $30.2 \pm 0.4^{* *}$ & $50.2^{*}$ & $>12.5[28 \%]^{\mathrm{b}}$ & $15 a$ & $8.3 \pm 0.2 *$ & 12.3 & $12.3 \pm 0.1^{*}$ \\
\hline 16 (maltosyl) & $51.3 \pm 1.7^{* *}$ & $125.5^{*}$ & $>12.5[20 \%]^{\mathrm{b}}$ & $16 \mathrm{a}$ & $63.3 \pm 8.3^{*}$ & $>123[65 \%]$ & $>12.3[44 \%]^{\mathrm{b}}$ \\
\hline 17 (gentiobiosyl) & nha $^{\mathrm{a}}$ & $\mathrm{nha}^{\mathrm{a}}$ & $>12.5[34 \%]^{\mathrm{b}}$ & $17 \mathbf{a}$ & $84.7 \pm 17.6$ & $>123[80 \%]$ & $>12.3[29 \%]^{\mathrm{b}}$ \\
\hline 18 (isomaltosyl) & nha $^{a}$ & nha $^{a}$ & $>12.5[33 \%]^{\mathrm{b}}$ & $18 \mathbf{a}$ & nha $^{a}$ & $>123[6 \%]$ & $>12.3[17 \%]^{\mathrm{b}}$ \\
\hline 19 (melibiosyl) & nha $^{a}$ & $\mathrm{nha}^{\mathrm{a}}$ & $>12.5[36 \%]^{\mathrm{b}}$ & 19a & $51.5 \pm 0.5^{* *}$ & $>123$ [95\%] & $>12.3[21 \%]^{\mathrm{b}}$ \\
\hline Sigma $^{\circledR}$ & $9 \mu \mathrm{g} / \mathrm{ml}$ & $30 \mu \mathrm{g} / \mathrm{ml}$ & & & & & \\
\hline $\mathrm{SN}-38$ & & & 0.1 & & & & \\
\hline
\end{tabular}

${ }^{\mathrm{a}}$ nha : no haemolytic activity;

${ }^{\mathrm{b}}$ cytotoxic activity observed at $10 \mu \mathrm{g} / \mathrm{ml}$.

$* P<0.01$, and $* * P<0.001$ represent significant differences which were calculated compared to $\alpha$-hederin (2)

using Student T-test.

Table 2.

Nuclei diameter, number of mitoses and apoptosis observed with KB cells by confocal imaging for saponins $(\mathbf{1 - 6}, \mathbf{8}, \mathbf{1 0}, \mathbf{1 3})$ and their methyl ester $(\mathbf{1 a - 3 a}, \mathbf{6 a}, \mathbf{8 a}, \mathbf{1 0 a}, \mathbf{1 3 a})$.

\begin{tabular}{|c|c|c|c|c|c|c|c|c|c|}
\hline & $\begin{array}{c}\text { concentration } \\
\mu \mathrm{M}\end{array}$ & $\begin{array}{l}\text { Nucleus } \\
\text { diameter } \\
\mu \mathrm{m} \pm \mathrm{SE}\end{array}$ & $\begin{array}{c}\text { mitosis } \\
\%\end{array}$ & $\begin{array}{c}\text { apoptosis } \\
\% \\
\end{array}$ & & $\begin{array}{c}\text { concentration } \\
\qquad \mu \mathrm{M}\end{array}$ & $\begin{array}{l}\text { Nucleus } \\
\text { diameter } \\
\mu \mathrm{m} \pm \mathrm{SE}\end{array}$ & $\begin{array}{c}\text { mitosis } \\
\%\end{array}$ & $\begin{array}{c}\text { apoptosis } \\
\% \\
\end{array}$ \\
\hline control & & $11.6 \pm 0.5$ & 0 & 0 & & & & & \\
\hline 1 & 8.3 & $17.1 \pm 0.6$ & $<1$ & 1 & 1a & 12.1 & $13.9 \pm 1.6$ & 0 & 0 \\
\hline \multirow[t]{2}{*}{2} & 3.3 & $12.3 \pm 1.0$ & $<1$ & 0 & $2 \mathbf{a}$ & 3.3 & $10.0 \pm 1.0$ & 0 & 0 \\
\hline & 6.7 & $10.3 \pm 0.3$ & 0 & 0 & & 6.6 & $12.5 \pm 1.0$ & 0 & 0 \\
\hline \multirow[t]{2}{*}{3} & 10.0 & $11.2 \pm 0.4$ & 1,4 & 15,7 & $3 \mathbf{a}$ & 9.8 & $9.2 \pm 0.4$ & 0 & $<1$ \\
\hline & 13.3 & $10.9 \pm 0.3$ & 2,5 & 14 & & 13.1 & $17.1 \pm 0.5$ & 0 & 0 \\
\hline 4 & 6.7 & $12.0 \pm 0.8$ & $<1$ & 1,9 & & & & & \\
\hline 5 & 13.3 & $11.8 \pm 0.7$ & 0 & 0 & & & & & \\
\hline \multirow[t]{2}{*}{6} & 6.8 & $10.8 \pm 0.6$ & $<1$ & $<1$ & $6 \mathbf{a}$ & 6.7 & 0 & & \\
\hline & & & & & & 10.0 & 0 & & \\
\hline \multirow[t]{2}{*}{8} & 6.8 & $10.6 \pm 0.6$ & 1,7 & 1.5 & $8 \mathbf{a}$ & 10.0 & 0 & & \\
\hline & 10.2 & 0 & & & & 13.3 & 0 & & \\
\hline 10 & 13 & $11.3 \pm 0.7$ & $<1$ & 4 & $10 a$ & 9.6 & 0 & & \\
\hline 13 & 6.5 & $11.9 \pm 1.0$ & 3.3 & 6 & $13 \mathbf{a}$ & 9.6 & 0 & & \\
\hline
\end{tabular}

